DOI https:// doi.org/10.32837/app.v63i0.18

УДК 316.614-053.6

Грона К. С. ${ }^{*}($ НУ «ОЮА»)

\title{
АГЕНТИ СОЦІАЛІЗАЦІЇ ТА ЇХ ВПЛИВ НА МОЛОДЬ
}

\section{SOCIALIZATION AGENTS AND THEIR IMPACT ON YOUTH}

*Kseniia Hrona - PhD Student (Political Science), Political Theories Department, National University "Odesa Law Academy" (23, Fontanska Doroha St., Odesa, Ukraine).

\section{Abstract}

The article analyzes primary and secondary agents of socialization, as well as examines in more detail the channels of influence on youth. The primary agents of socialization are family, friends, peers. Agents of secondary socialization are stateowned societies, various political institutions (parties, associations, media, etc.).

The study found that the impact on youth is evenly distributed, but channels of formation, namely social networks, have become more influential (Facebook, Instagram, Tik-Tock). It has also been found that the institutions involved in youth formation have not gained much popularity through various activities and promotions.

The main problems of the state and society in the process of socialization of young citizens have been clarified. They revealed the next problems: aging workforce, lack of a strategy for promoting state institutions among young people, low financial resources of young people from the state, imperfect legislation, statistical role of local self-government bodies.

Some solutions to particular aspects of youth policy implementation will be offered, which will increase the interaction between the state and society, as well as increase the level of trust in the authorities.

Although there is still no complete and clear portrait of the future citizen of the Ukrainian state in the consciousness of society, all the necessary conditions for the comprehensive development of people aged 14-35 are being created.

Keywords: socialization, agents of primary socialization, agents of secondary socialization, information channels, information network channel, officially institutional channel. 
У зв' язку з історичним розвитком суспільства змінилась свідомість людей, і українське суспільство не є виключенням. До основних цінностей (любов, сім'я, добробут і т.д.) додались інші, такі як: свобода, рівність можливостей, демократія. 3'явились нові та змінились старі норми соціальної поведінки (етикет спілкування за допомогою мережі Інтернет, відношення до життєвої позиції, дітей та інше), які потребують детального розгляду. Норми соціальної поведінки у кожному громадянському суспільстві формуються індивідуально, адже багато факторів впливають на це, таке явище можна назвати відносною девіацією. Кожне суспільство виробляє свої взірці соціально прийнятної поведінки.

Об'єктом дослідження виступає молодь. Вплив на формування даної верстви населення здійснюють агенти первинної та вторинної соціалізації за допомогою імпульсів. Під агентами первинної соціалізації мається на увазі сім'я, друзі, однолітки. Агентами вторинної соціалізації виступають суспільство в обличчі держави, різноманітні політичні інститути (партії, об'єднання, 3МІ та інше).

Розглянемо детальніше агентів соціалізації. Як вже зазначалося вище, агентами первинної соціалізації виступають сім'я (близькі або далекі родичі), однолітки, вчителі, лікарі та інші.

Інститут сім'ї закладає основні норми поведінки, які стосуються майже всіх сфер життєдіяльності молодої людини. Батьки 3 раннього віку прищеплюють основи культурної спадщини, цінностей, що властиві конкретному суспільству. На ранньому етапі, в період формування особистості, підлітку пояснюють правила етикету поведінки в сім'ї. Наприклад, шанобливе ставлення до будь-якого члену сім'ї, незалежно від віку; розкриття сутності понять взаєморозуміння, довірчих відносин; поняття особистого простору, власності речей. Надалі, у міру занурення дитини в суспільство, освоюються норми поведінки, які дозволяють з комфортом співіснувати у суспільстві.

Спілкування з однолітками, друзями формують вподобання людини, виходячи з яких виробляється лінія поведінки, властиві тій чи іншій культурі. Не завжди, підростаюче покоління віддає свій вибір загальноприйнятому. У підлітковому віці, в період особистісного становлення, індивід часто стає представником субкультури. Під терміном субкультури мається на увазі добровільне об'єднання, яке характеризується самостійною системою символів, цінностей і відрізняється від загальноприйнятих стандартів. У сучасному світі 
представники таких рухів не схвалюють громадських правил, проте, діють в їх рамках, таке явище називається навернення суспільства.

На даному історичному етапі, рухи XX століття відпали за необхідністю і з' явилися нові. Не можливо не відзначити надмірного впливу різноманітних культур на розуми сучасного покоління. Субкультури сприяють індивідуалізації особистості та в водночас соціалізують їі. Наприклад, широке поширення набула «Аніме» культура з своїми касплеями, в яких молодь прагне максимально наслідувати улюблених персонажів мультфільмів. Для Японії таке явище в порядку речей, для країн СНД певною мірою, це явище залишається «диким» для дорослого покоління, а молодь в повній мірі пізнає таїнства перевтілення, отримуючи задоволення від процесу та результату.

У Європі субкультура «аніме» проявилася, як рух «рольовиків». Воно характеризується тим, що будь-який бажаючий, переодягнувшись в будь-який персонаж, може взяти участь у відтворенні будь-якої історичної або казкової події. Українська молодь, також перейняла тенденцію і часто приймає участь рольових середньовічних турнірах. Побачити таке можливо на різних фестивалях, що проходять на території історично - архітектурних пам'ятників України (Аккерманська фортеця, Одеська область, фортеця в Кам'янецьПодільському).

Різноманіття субкультур велике. Існують такі, що сприяють лише на користь людині, проте бувають і дуже агресивні культури (для задоволення власних потреб необхідно здійснити протиправне діяння). У будь-якому випадку, в період формування особистості, необхідно брати участь в житті підлітка. Така позиція аргументується тим, що агенти первинної соціалізації є безпосереднім прикладом наслідування. Саме на них, покладено обов'язок спостерігати, надавати підтримку, а в деяких випадках втручатися в процес соціалізації молодого індивіда.

Як вже зазначалось, до агентів вторинної соціалізації відносять: державу, різноманітні державні установи, громадські організації, партіі, 3МI ті інші.

Пропоную детальніше розглянути основні складові інституційної структури суспільства, які впливають на молодь. Слід зазначити, що за даними щорічної доповіді Президентові України, Верховній Раді України, Кабінету Міністрів України про становище молоді в Україні (надалі «Молодь - 2018») зазначається, що станом на 1 січня 2018 року на території держави проживає понад 11,2 мільйонів молодих лю- 
дей віком 14 - 35 років (27\%), окрім тимчасово окупованої території Донецької та Луганської областей, АР Крим та м. Севастополя (Геєць, 2011). Це означає, що незалежно від географічного положення, перед державою стоїть важлива місія інтеграції молодих людей до суспільства, а також вироблення потреби до групового та індивідуального розвитку. Головним інструментом, у даному випадку, виступає інформація, яка поширюється за допомогою каналів. Також, необхідно пам'ятати, що молодь XXI століття називають покоління Z, або поколінням digital natives. Його представники виросли з екранами в руках; інтернет для них - не засіб розваги, а середовище проживання. Тому, доцільно розглянути інформаційні канали детальніше. Відповідно до цього, розрізняють інформаційно - мережевий та офіційно - інституціональний канали (Прохоренко, 2016).

Під інформаційно - мережевим каналом розуміють усю інформація, що знаходиться у мережі Інтернет. Зважаючи на його значне розповсюдження, збільшення кількості користувачів, підвищення рівня послуг, швидкість доступу до мережі та мобільність, Інтернет відіграє все більше значущу роль у житті молоді.

Мережа є зручним засобом для обміну інформації між комунікантами. Проте, інформаційні канали змушені трансформувати форму викладення свого матеріалу, пропонуючи аудиторії найбільш спрощений варіант подачі інформації у вигляді тез, окремих коротких повідомлень, фрагментів, таке явище отримало назву «кліп-культура». Вважається, що вперше поняття «кліп-культура» як принципово нове явище було виділено американським письменником та футуристом Елвіном Тоффлер на рубежі 70-х - 80-х років XX століття, у книзі «Третя хвиля» (Прохоренко, 2016).

Молодь отримала можливість швидко споживати великий масив інформації, але разом із тим, джерела інформації отримали змогу маніпулювати суспільством, нав' язуючи необхідну точку зору, за допомогою спотворення та підробки фактів. Водночас, 3 'явилось багато психологічних проблем та фобій пов'язаних з віртуальною реальністю.

Стосовно контенту, який споживають, він поділяється на інформаційний та розважальний.

Інформаційний контент - інформація, яка корисна читачеві, допомагає задовольнити потреби та досягнути мети. В рамках нашого дослідження, корисно розглянути вплив інтернет видань на політичну соціалізацію та формування громадянської активності. За даними 
доповіді «Молодь - 2018» серед 2000-х опитаних респондентів, лише 8,9\% постійно стежать за політичним життям в Україні. 25,9\% цікавляться головними подіями політики, інші 65,2\% опитаних - рідко, або зовсім не цікавляться політичними подіями держави. Якщо ранжувати за віковим цензом, найбільш політично соціалізованими є молодь віком 25-29 років (39,7\%), на другому місці - 30 - 34 років $(38,4 \%)$, третє місце займають громадяни віком 20 - 24 років (32,3\%) (Дмитрук, Паданка, Тілікіна, Кірєєв, 2018).

Вище викладені статистичні дані говорять, про те що держава приділяє недостатньо уваги вихованню молоді, а також в неповній мірі використовує існуючі ресурси.

На сьогоднішній день, в українських реаліях існує проблема довіри 3МI, найбільш авторитетними джерелами інформації виявились інтернет-видання (43,7\%) та соціальні мережі (47\%) (Дмитрук, Паданка, Тілікіна, Кірєєв, 2018). Такі статистичні данні дають змогу зрозуміти, що ключовим інструментом реалізації державної політики повинен стати Інтернет. На зміну індустріальному прийшло інформаційне суспільство, яке більш охоче приймає участь у державотворчому процесі за допомогою електронної демократії, соціальних мереж.

Соціальні мережі дозволяють відновити втрачені зв'язки, розширювати та зміцнювати наявні (Геєць, 2011). Також, основним завданням таких майданчиків, це змусити посміхнутись, тому 70\% контенту - розважальний. На даний момент, у 2019 році найбільш популярними соціальними мережами, де зареєстрована українська молодь є: Facebook (FB), Instagram, Tik-tok.

Із закриттям доступу до «Вконтакте» у 2017 році за наказом президента П.Порошенка, кількість користувачів FB зросла. На момент 2018-2019 років, за статистикою сайту gs.statcounter.com, кількість перегляду сторінок з урахуванням всіх платформ: ПК, Смартфони, Планшети, Консоль, що мають український IP - адрес становить приблизно 70\% населення України (Ринок браузерів у всьому світі березень 2018 - березень 2019). Специфікація даної соціальної мережі - новини, спосіб вираження своєї громадянської позиції та просто спілкування. На сьогоднішній день, на FB іноді роблять посилання, а іноді навіть використовують як достовірне джерело інформації. Це пояснюється тим, що кожний поважаючий себе політик чи громадський діяч має акаунт у мережі, за допомогою якого спілкується з суспільством. Користувачів віком від 14 до 35 років нажаль не так багато. 
Другим за популярністю серед молоді є мобільний додаток Instagram. Основним способом донесення інформаціє є тридцяти секундні відеоролики або яскраві зображення з коротким текстом під ним. За статистичними даними gs.statcounter.com, станом на вересень 2018 року кількість активних споживачів сягала 16,7\% населення України, більшість з яких є молодь.

I останній, але не менш популярний додаток - Tik-Tok. Специфікація - розважальний контент. До позитивних аспектів мережі слід віднести можливість через додаток проявити креативність, поділитись цікавими моментами життя. Надає змогу наслідувати вподобані звуки або особистості, що безумовно розважає та об'єднує аудиторію за інтересами.. Спосіб спілкування - взаємний обмін «like» під відео чи коментування його. Аудиторія - громадяни віком 14 - 35 років. За офіційними даними додатку, у червні 2018 року, це найбільш скачуваний додаток на сервісах App Store та Google Play, а офіційних користувачів понад 500 мільйонів людей з усього світу. Стосовно користувачів українських IP адрес, за статистичними даними того ж самого додатку, середня кількість витраченого часу на Tik-Tok становить приблизно 50 хвилин на день.

Нажаль, державні структури не розвивають сторінки у Instagram та Tik-Tok чи інших соціальних мережах, окрім FB. На мою думку, якщо профільні державні установи (в рамках дослідження молоді), яскравіше висвітлювали свою діяльність, то обізнаність та активність молоді у державотворенні значно зросла. Основною проблемою державних структур, що займаються молодіжною політикою, є проблема відсутності грамотної SMM стратегії просування. А також, існує тенденція "старіння" посадових осіб, адже середній вік трудових кадрів становить приблизно 35 - 45 років. В той самий час, кількість молоді на державній службі становить приблизно 30\%. Останнім часом, спостерігається тенденція до зростання кількості молодих людей на державній службі та в органах місцевого самоврядування. Проте, в той самий час, спостерігається найбільша плинність молодих кадрів. Основною причиною цього $є$ недостатнє матеріальне забезпечення (Покотило, 2015).

За результатами досліджених даних, пропонується:

1. кадрова реструктуралізація:

2 створення сприятливих умов (пільг, заохочень, підвищення рівня заробітної платні);

3. створення посади SMM спеціалістів. У кожному профільному напрямку має бути такий спеціаліст, для більш активного залучення цільової аудиторії до реалізації молодіжної політики. 
Офіційно-інституційний канал реалізовує свою діяльність за допомогою телебачення, радіо, преси. Основною проблемою цих засобів масової інформації є низький кредит довіри. За результатами дослідження «Молодь - 2018», лише 24,8\% респондентів відповіли, що повністю або частково довіряють інформації з газет. Водночас, 32,1\% респондентів відповіли, що мають кредит довіри до телебачення (Дмитрук, Паданка, Тілікіна, Кірєєв, 2018). До інституційних каналі відносять: урядові видання, ТВ канали (РАДА), офіційні сайти державних органів. 3 такими джерелами інформації, зазвичай ознайомлені підконтрольні державні органи, що здійснюють владу на місцях. Нажаль, такі низькі показники є результатом багаторічної неефективної роботи державних установ, а також втрата довіри до політиків.

Узагальнюючи вище викладений матеріал, складається стійка думка, що засоби масової інформації як інститут вторинної соціалізації займає чи не найголовнішу роль у формуванні молодої верстви населення, після інституту освіти.

Якщо формування особистості під впливом 3МІ проходить не контрольовано, то інститут освіти - це більш формалізований канал соціалізації. Основною функціями є забезпечення соціальних змін та розвиток суспільства створення національної школи, сприяння соціальній стабільності та інтеграції. До основних проблем, що вирішує освіта належить проблема поведінки людини в освітянському просторі, її ставлення до навколишнього середовища.

Освітня система України - сукупність навчальних закладів, навчально-методичних рекомендацій та освітніх програм. 3 організаційної точки зору система освіти в Україні складається з учбових закладів різного профілю та типу акредитації. У рамках дослідження молоді, нас цікавить загальна середня, професійно-технічна, вища та позашкільна освіта.

Загальна середня освіта - сприяє розвитку підлітка як особистості, iї потенціалу, творчих схильностей, професійне самовизначення, а також сприяє формуванню загальнолюдської моралі, надає необхідні знання про природу, людину та суспільство, здійснює екологічне та фізичне виховання.

Позашкільна освіта та виховання - забезпечує творчий розвиток підлітка в системі позашкільних освітньо-виховних закладів. В якості прикладів можна навести: центри патріотичного виховання, дитячоюнацькі спортивні школи, дитячо-юнацькі табори та інші. 
Професійно-технічна освіта - здійснює навчання робітничих професій відповідно до схильностей, інтересів, здібностей. А також забезпечує підвищення виробничої кваліфікації, перепідготовку.

Вища освіта - забезпечує фундаментальну наукову та загальнокультурну, практичну підготовку, одержання громадянами спеціальності відповідно до покликання, інтересів, здібностей, підвищення їхньої кваліфікації, вдосконалення професійної підготовки, перепідготовку наукових і науково-педагогічних кадрів (Лукашевич, Туленков, 2005).

Держава всебічно сприяє вирішенню проблем освітнього процесу, на законодавчому рівні, існують усі необхідні документи. Проте існує перелік проблем: омолодження кадрів, низька заробітна плата, проблема підготовки кваліфікованих кадрів, матеріальне забезпечення учбового процесу та інші. Варто враховувати, що реалізація освітнього процесу має ієрархічну структуру, проте самі громадяни не можуть впливати чи змінювати процес навчання. Безумовно усі перелічені недоліки заважають повноцінно сприяти соціалізації молоді.

На локальному рівні соціалізація також здійснюється за допомогою територіальних громад. Відповідно до статті 1, Закону України «про місцеве самоврядування», територіальна громада - жителі, об'єднані постійним проживанням у межах села, селища, міста, що $є$ самостійними адміністративно-територіальними одиницями, або добровільне об'єднання жителів кількох сіл, що мають єдиний адміністративний центр (Закон про місцеве самоврядування України від 21 травня 1997 р. № 280/97-ВР). Основною метою самоорганізації населення - реалізація власних потреб. Відповідно до цього, громада має власні представницькі органи місцевого самоврядування, районні та обласні ради, виконавчі органи, а також органи самоорганізації населення.

Що стосується молоді, до основних способів участі у місцевому самоврядуванні з 18 років виражається шляхом: участі у виборах органів місцевого самоврядування; здійснення контролю за діяльністю органів виконавчої влади; участь у обговоренні проектів рішень місцевого рівня; внесення пропозицій, щодо соціально-економічного розвитку громади; інше. Молодь, яка ще не досягла виборчого віку, має змогу допомогти свойй громаді в облаштуванні свого населеного пункту (колективні суботники, висаджування дерев, інше).

За результатами «Молодь - 2018», активну участь у розбудові та розвитку власної об'єднаної територіальної громади (ОТГ) 
лише 24,4\% готові до активних дій. 22,3\% відповіли, що скоріше не братимуть участь у розбудові громади, 31,2\% взагалі не збираються розвивати свої ОТГ (Дмитрук, Паданка, Тілікіна, Кірєєв, 2018).

На сьогоднішній день, комунікація між людьми на місцевому рівні майже не відбувається, що уповільнює місцевий розвиток і трансформацію суспільства у більш цивільну форму організації. Нажаль, більшість місцевих організацій виникають через кон'юнктурні інтереси - це пояснюється тим, що частка з них функціонує лише під час електорального процесу, за для створення позитивного іміджу кандидата.

Нині в Україні відбувається якісно новий етап реформації самоорганізації населення, проте існують істотні перешкоди, зокрема: низький рівень взаємодії органів місцевого самоврядування та органів самоорганізації населення у вирішенні соціальних проблем, недосконале законодавство, дефіцит ресурсної бази в органів самоорганізації населення для реалізації ними власних повноважень, тощо. Іноді для досягнення мети, громадяни однієї спільноти створюють громадські організації (ГО) чи партії.

Необхідно підкреслити, що громадські об'єднання долучаються до процесу соціалізації не лише на етапі становлення та розвитку громадянського суспільства.

Основною метою неурядових організацій є поліпшення життєдіяльності людей, а також сприяння соціалізації. Реалізовуючи свою діяльність керуються принципами демократизму, соціальної справедливості, верховенства права. До основних функцій, пов'язаних з процесами соціалізації, є:

- надання допомоги незахищеним верствам населення;

- боротьба з бідністю;

- створення та реалізація додаткових освітніх програм, професійне зростання та перепідготовка кадрів;

- благодійність;

- організація дозвілля та відпочинку для членів організації;

- здійснення захисту прав та свобод своїх інтересів;;

- сприяння становленню ідеологічної основи громадянського суспільства: виховання відчуття відповідальності, бажання бути частиною колективу, суспільних процесів, що відбуваються в державі та суспільстві тощо;

- здійснення контролю за діяльністю влади, недопущення фактів корупційної діяльності. 
Не дивлячись на різноманіття законів, які регулюють діяльність ГО існує багато проблем: не значне фінансування програм та заходів ГО, низький відсоток залученості молоді, недовіра з боку населення, що не є членами організацій, а також практика відмивання грошей. За статистичними даними, 80,5\% молоді не брали участі у діяльності жодної організації громадянського суспільства; 7,9\% брали участь у шкільному чи студентському самоврядуванні; $5,1 \%$ є учасниками спортивних організацій, або пов' язаних з проведенням дозвілля; 4,1\% приймали участь у волонтерських ініціативах. Безумовно, такі показники дуже низькі, проте українське суспільство активно змінюється на краще.

Що стосується політичної соціалізації, існує проблема персоніфікації суб'єктів навчання. Тобто серед усіх інститутів, жоден не займається політичною освітою молоді, окрім учбових закладів, що викладають політологію. Загалом, в українських реаліях існують лише політичні партії, основною метою яких є боротьба та догнення влади. Молодь взагалі не реалізовує свої політичні права, до яких відносять: підписання політичних вимог/підтримка онлайн-петицій; участь у мирних демонстраціях, мітингах, протестах (окрім за гроші); участь у волонтерських рухах або громадянських організаціях; робота в політичних партіях та інше.

Незважаючи на щорічне зростання кількості політичних організацій та політичних партій в Україні, цей інститут не став дієвим інструментом процесу політичної соціалізації, слабо впливають на формування політичної культури, консолідацію нації і виховання політичної еліти.

Таким чином, здійснивши аналіз існуючих інститутів, що безпосередньо займаються соціалізацією молоді, у своєму дослідженні дійшла наступних висновків:

1. Законодавча база загалом відповідає потребам сьогодення, проте на практиці не реалізується у повній мірі. Молодь, лише після Революції гідності, визначилась з пріоритетними напрямками власного розвитку, з'явилась самосвідомість і бажання брати активну участь в розбудові держави.

2. Здійснюється щорічний моніторинг особистісного портрету молоді, але нажаль результати свідчать про бездіяльність держави та суспільства;

3. Виявлено, що основним інструментом дії - інформація, а середовище в якому іiї необхідно використовувати - кіберпространство. 
Зовнішній вигляд може бути любим, хоча перевагу ліпше віддати відео-контенту.

Резюмуючи викладене, пропонується:

1. Приділяти більшу увагу до висвітлення діяльності профільних установ. Розробка SMM стратегії та ефекту присутності у мережі. Публікувати інформацію не лише про офіційні зустрічі та підписання договорів, а висвітлювати закулісне життя державних установ, більше контенту з різноманітних заходів, що відбуваються у різних регіонах України.

2. Проводити освітню діяльність для усіх інститутів, що взаємодіють 3 молоддю. Наприклад, програма «Молодіжний працівник».

Іншими словами, Україна знаходиться на новому історичному етапі, де суспільству не байдуже, що відбувається навколо нього. Молодь стала розумнішою та активнішою. На сьогоднішній день, нові прояви суспільної свідомості все рідше керуються встановленими раніше традиціями, нормами. Стан масової свідомості населення, і перш за все молоді, характеризується прогресивністю настроїв та думок, що безумовно не може не радувати.

\section{Лimepamypa:}

Геєць В. М. (2011). Інститути соціалізації в Україні та країнах СС: тенденції розвитку та ключові відмінності. Український соціум, 2, 7-34. <http://nbuv.gov.ua/UJRN/Usoc_2011_2_3>.

Дмитрук Н., Паданка Г., Тілікіна Н., Кірєєв С. (2018). «Молодь - 2018»: Результати репрезентативного М 75 дослідження (м. Київ, 2018 р.). <http:/ / www.dsmsu.gov.ua/media/2019/01/08/9/Doslidjennya_ broshyra.pdf $>$.

Закон про місиеве самоврядування України від 21 травня 1997 р. № 280/97-ВР (Верховна Рада України). <https://zakon.rada.gov.ua/ laws/show/280/97-вр>.

Лукашевич М. П., Туленков М. В. (2005). Соціологія. Базовий курс: Підручник. К.: Каравела. <https://studfiles.net/preview/5647951/ page:29/>.

Милош И. (2018). Каждая секунда на счету. Почему полмиллиарда пользователей без ума от приложения TikTok. Sostav.ru - новости рекламы и маркетинга. <https:/ / www.sostav.ru/publication/kazhdayasekunda-na-schetu-pochemu-polmilliarda-polzovatelej-bez-uma-ottiktok-33962.html>. 
Покотило Т. В. (2015). Формування та розвиток якісних характеристик трудового потенціалу в органах місцевого самоврядування. Теорія та практика державного управління, 4(51), 170-178.

Прохоренко Т. Г. (2016). Соціалізація молоді в інформаційному суспільстві: особливості та ризики. Вісник Національного університету «Юридична академія України імені Ярослава Мудрого», 2 (29), 128-133.

Ринок браузерів у всьому світі березень 2018 - березень 2019. $<$ http:/ /gs.statcounter.com/ social-media-stats>.

Ярошенко О. В., Аксьонова С. Ю. та ін. (2018). Участь молоді в процесах реформування держави. Щорічна доповідь Президентові України, Верховній Раді України, Кабінету Міністрів Украӥни про становище молоді в Україні (за підсумками 2017 року). Київ: Держ. ін-т сімейної та молодіжної політики. <http:/ / www.irbis-nbuv.gov.ua/cgibin/irbis_nbuv/ cgiirbis_64.exe?I21DBN=LINK\&P21DBN=UJRN\&Z21ID=\&S21REF= $10 \& S 21 C N R=20 \& S 21 S T N=1 \& S 21 F M T=A S P \_m e t a \& C 21 C O M=S \& 2$ S21P03=FILA=\&2_S21STR=Usoc_2011_2_3>.

\section{References:}

Dmy`truk N., Padanka G., Tilikina N., Kiryeyev S. (2018). «Molod 2018»: Rezul'taty' reprezentaty 'vnogo M75 doslidzhennya [Youth 2018: Results of a Representative M75 Study (Kyiv, 2018)] (m. Ky`yiv, 2018 r.). <http://www.dsmsu.gov.ua/media/2019/01/08/9/Doslidjennya_broshyra.pdf $>$. [in Ukrainian].

Geyecz` V. M. (2011). Insty`tuty` socializaciyi v Ukrayini ta krayinax YeS: tendenciyi rozvy 'tku ta klyuchovi vidminnosti [Institutions for socialization in Ukraine and the EU: trends and key differences]. Ukrayins `ky j socium [Ukrainian Society], 2, 7-34. <http://nbuv.gov.ua/ UJRN/Usoc_2011_2_3>. [in Ukrainian].

Lukashevy`ch M. P., Tulenkov M. V. (2005). Sociologiya. Bazovy`j kurs: Pidruchny`k [Sociology. Basic Course: Tutorial]. K.: Karavela. <https:/ / studfiles.net/preview/5647951/page:29/>. [in Ukrainian]. Milosh I. (2018). Kazhdaya sekunda na schetu. Pochemu polmilliarda polzovateley bez uma ot prilozheniya TikTok [Every second counts. Why is half a billion users crazy about the TikTok app]. Sostav.ru - novosti reklamy $i$ marketinga [Sostav.ru - news of advertising and marketing]. <https:// www.sostav.ru/publication/kazhdaya-sekunda-na-schetupochemu-polmilliarda-polzovatelej-bez-uma-ot-tiktok-33962.html>. [in Russian]. 
Pokoty`lo T. V. (2015). Formuvannya ta rozvy`tok yakisny`x xaraktery`sty`k trudovogo potencialu v organax miscevogo samovryaduvannya [Formation and development of qualitative characteristics of labor potential in local self-government bodies]. Teoriya ta prakty ka derzhavnogo upravlinnya [Public Administration Theory and Practice], 4(51), 170-178. [in Ukrainian].

Proxorenko T. G. (2016). Socializaciya molodi v informacijnomu suspil`stvi: osobly`vosti ta ry`zy`ky` [Youth socialization in the information society: features and risks]. Visny'k Nacional nogo universy tetu "Yury`dy 'chna akademiya Ukrayiny' imeni Yaroslava Mudrogo» [Bulletin of the National University "Yaroslav the Wise Law Academy of Ukraine»], 2 (29), 128-133. [in Ukrainian].

Ry nok brauzeriv u vs 'omu sviti berezen ' 2018 - berezen 2019 [Worldwide Browser Market March 2018 - March 2019]. <http:/ / gs.statcounter.com/ social-media-stats>. [in Ukrainian].

Yaroshenko O. V., Aks`onova S. Yu. ta in. (2018). Uchast molodi $v$ procesax reformuvannya derzhavy'. Shhorichna dopovid Prezy'dentovi Ukrayiny', Verxovnij Radi Ukrayiny', Kabinetu Ministriv Ukrayiny pro stanovy'she molodi v Ukrayini (za pidsumkamy' 2017 roku) ' [Youth participation in the processes of state reform. Annual report to the President of Ukraine, the Verkhovna Rada of Ukraine, the Cabinet of Ministers of Ukraine on the situation of young people in Ukraine (as of 2017)]. Ky`yiv: Derzh. in-t simejnoyi ta molodizhnoyi polity`ky. <http://www.irbisnbuv.gov.ua/cgibin/irbis_nbuv/cgiirbis_64.exe?I21DBN=LINK\&P21D $\mathrm{BN}=\mathrm{UJRN} \& Z 21 \mathrm{ID}=\& S 21 \mathrm{REF}=10 \& S 21 \mathrm{CNR}=20 \& S 21 \mathrm{STN}=1 \& S 21 \mathrm{FMT}=$ ASP_meta\&C21COM=S\&2_S21P03=FILA=\&2_S21STR=Usoc_2011_2_3>. [in Ukrainian].

Zakon pro misceve samovryaduvannya Ukrayiny vid 21 travnya 1997 r. \# 280/97-VR (Verxovna Rada Ukrayiny`) [Law on Local Self-Government of Ukraine of May 21, 1997 No. 280/97-VR (Verkhovna Rada of Ukraine)]. <https:/ zakon.rada.gov.ua/laws/show/280/97-vr>. [in Ukrainian].

\section{Анотація}

Грона К. С. Агенти сочіалізачї̈ та їх вплив на молодъ. - Стаття.

У статті проведено аналіз первинних та вторинних агентів соијілізації, а також більш детально розглянуто канали впливу на молодь. Проаналізовані інститути, що прииммають участь у формуванні молоді. За результатами дослідження Виявлено, основні проблеми держави та суспільства у процесі соціалізації молодих громадян. Запропоновано варіанти рішень деяких аспек- 
тів реалізації молодіжної політики, що підвищать взаємодію між державою та суспільством, а також підвищзать рівень довіри до влади. Хоча в свідомості суспільства досі відсутній повний $і$ чіткий портрет майбутнъого громадянина Української держави, нині створюються усі необхідні умови для всебічного розвитку ююдей Віком 14-35 років.

Ключові слова: соціалізація, агенти первинної соціалізаціӥ, агенти вторинної соціалізації, канали інформації, інформаційно-мережевий канал, офіціийно-інституційний канал. 